\title{
Clarification of purple cactus pear juice using microfiltration membranes to obtain a solution of betalain pigments
}

Clarificação de suco de figo da índia do tipo púrpura com membranas de microfiltração para obtenção de uma solução de pigmentos de betalaínas

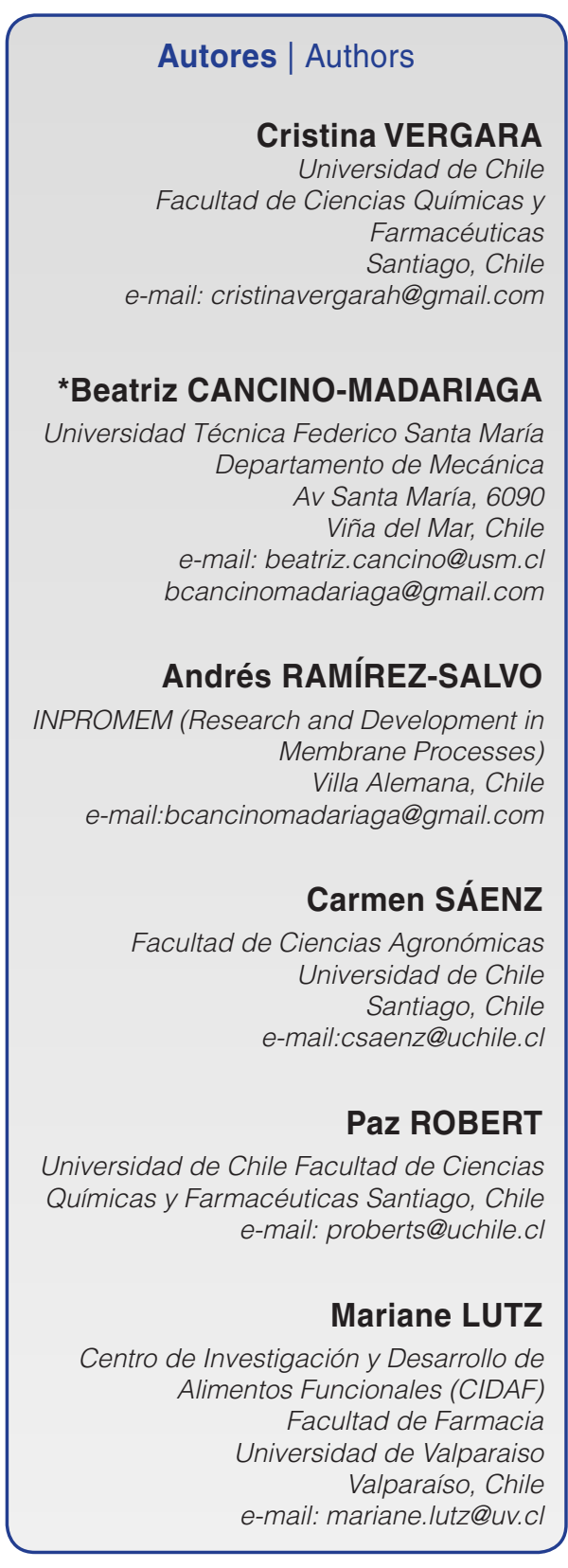

*Autor Correspondente / Corresponding Author

Received: Sept. 05, 2014

Approved: Aug. 11, 2015

\section{Summary}

Betalains are fruit pigments possessing health-giving properties. To isolate the pigments, the juice must be separated from the fruit matrix, which contains biopolymers. The aim of this study was to clarify cactus pear juice by microfiltration to obtain a clarified juice containing betalains. For this purpose, two $0.2 \mu \mathrm{m}$ pore size microfiltration membranes (ceramic and polymeric) were tested. The permeates were clear, free of turbidity and high in betalains (20\%), also containing polyphenols and antioxidant activity, whereas the retained fractions were high in mucilage. The best separation was obtained using the ceramic membrane.

Key words: Microfiltration; Cactus pear juice; Betalains; Mucilage; Clarification.

\section{Resumo}

Betalaínas são pigmentos de frutos que possuem propriedades benéficas à saúde. Para isolamento dos pigmentos, o suco deve ser separado da polpa da fruta, que contém biopolímeros. O objetivo deste estudo foi clarificar o suco de figo da índia utilizando microfiltração para obtenção de um suco clarificado contendo betalaínas. Para isso, duas membranas de microfiltração (cerâmica e polimérica) de $0,2 \mu \mathrm{m}$ de tamanho de poro foram testadas. O permeado obtido foi límpido, livre de turbidez e concentrado em betalaínas (20\%), contendo também polifenóis e atividade antioxidante, enquanto que a fração retida foi concentrada em mucilagens. A melhor separação foi obtida usando a membrana cerâmica.

Palavras-chave: Microfiltração; Suco do figo da índia; Betalaínas; Mucilagem; Clarificação. 


\section{Introduction}

Cactus pear (Opuntia sp) is cultivated in arid and semiarid regions. The green ecotype is well known and has been cultivated for many years in many regions throughout the world. Some less well-known ecotypes yield other coloured fruits: purple, red, yellow and orange (CASTELLAR et al., 2006; DÍAZ et al., 2006; TESORIERE et al., 2005). The purple ecotype contains betalain pigments providing its characteristic colour. Furthermore, cactus pear is one of the few natural sources of betalains, which are also found in beetroot, amaranth and some other Cactaceae such as the cactus pear, pitaya (Stenocereus sp.), pitahaya (Hylocereus undatus) and garambullo (Myrtillocactus geometrizans) (CAl et al., 1998; CASTELLAR et al., 2006; DÍAZ et al., 2006; TESORIERE et al., 2005). Betalains are water-soluble pigments comprising two structural groups: betacyanins (red-purple) and betaxanthins (orange-yellow) (CASTELLAR et al., 2003; DELGADOVARGAS et al., 2000; FORNI et al., 1992; SÁENZ, 2006). The main betacyanin pigment in purple cactus pear (Opuntia ficus-indica) is betanin, although low levels of isobetanin have also been detected (both pigments have a red colour). The yellow colour is mainly produced by the betaxanthin pigment indicaxanthin (CASTELLAR et al., 2003; FERNÁNDEZ-LÓPEZ; ALMELA, 2001; SÁENZ et al., 2009). Both pigments are found in the pulp and peel of the cactus pear. The betalain content of the fruit is affected by several factors, including the cultivar or variety, stage of maturity, climate and geographical location, amongst others (CASTELLAR et al., 2003; SEPÚLVEDA et al., 2003; STINTZING; CARLE, 2004; ODOUX; DOMÍNGUES-LÓPEZ, 1996). The intake of betalains may provide protection against diseases related to oxidative stress. The consumption of cactus pear fruit and beet juice positively affect the body's redox balance and decrease oxidative damage, amongst other beneficial effects (SEMBRIES et al., 2006; TESORIERE et al., 2004; GENTILE et al., 2004; SEMBRIES et al., 2006; SREEKANTH et al., 2007). Few scientific studies have reported the presence of antioxidant phenolic compounds in cactus pear fruit. The purple Opuntia ficus-indica ecotype contains a large amount of total phenolics of up to $660 \mathrm{mg} / \mathrm{L}$ in the juice (GALATI et al., 2003) and up to $900 \mathrm{mg} / \mathrm{L}$ in the fruit (SÁENZ at al., 2009). Other studies have identified the presence of flavonoids such as flavonol glycosides, including significant amounts of isorhamnetin-3-rutinoside, rutin, kaempferol-3-rutinoside and quercetin in a blend of yellow, purple and red cultivars (STINTZING et al., 2005; KUTI, 2004). The intake of polyphenols has been inversely correlated with the incidence of several chronic diseases, including various types of cancer and cardiovascular diseases (STEVENSON; HURST, 2007). Cactus pear pulp, containing betalains and polyphenols, could therefore be used as a functional ingredient in the food industry, with applications as a potentially health-giving natural food colour.

The current source of commercial betalains, which have been used as natural food colours for many years, is beetroot (Beta vulgaris) (SERRIS; BILIADERIS, 2001). Betanin (also termed "beetroot-red") is accepted amongst the natural pigments that are classified as additives E-162 (European Union) and 73.40 (FDA) (CASTELLAR et al., 2006). It is used mainly in foods that do not require thermal treatment, such as yogurt, confectionery, ice cream, syrups and sausages (FORNI et al., 1992; DÍAZ et al., 2006). However, beetroot normally requires cooking to remove 3-secbutyl-2-methoxipyrazine, which is toxic to humans, and it is also necessary to remove the earthy flavour of geosmin. Cactus pear does not have these disadvantages and thus the pigment solution can be extracted directly from the juice without the need for thermal treatment. Furthermore, since the cactus crop does not accumulate nitrates, it represents a lower risk of microbiological contamination (STINTZING et al., 2001; MOBHAMMER et al., 2006). Consequently, the purple cactus pear represents a promising alternative for the production of these natural dyes.

The stability of betalains is affected by temperature, water activity, $\mathrm{pH}$, metals, enzymes, light and oxygen, and in fact, a lack of stability can sometimes lead to a total loss of colour.

The temperature used during both food processing and storage can be considered as the most important factor affecting betalain stability (CASTELLAR et al., 2003; HERBACH et al., 2006; AZEREDO, 2008). Therefore separation procedures that avoid thermal treatment, such as membrane technologies, should be used to protect the pigments.

Compared with traditional separation and clarification methods, membrane technology, and specifically microfiltration (MF), appears to be feasible for the processing of betalains since it is an economical, non-thermal separation technique that does not require the use of chemical agents (CASSANO et al., 2010). Membrane separation is mainly based on differences in particle size, and depends on the selective permeability of the membrane under a hydrostatic pressure gradient (CHERYAN, 1998). MF has a separation range of approximately 10 to $0.1 \mu \mathrm{m}$ and is normally used in the food industry for clarification, cold pasteurisation and casein separation (CANCINO-MADARIAGA et al., 2008; ESPINA et al., 2010). Both ceramic and polymeric membranes can be used in this range of particle size.

The main challenge in the separation of the red pigment from the cactus pear pulp is the mucilage, a complex mixture of polysaccharides, less than $50 \%$ of 
which corresponds to a pectin-like polymer (SÁENZ, 2004; MATSUHIRO et al., 2006). The traditional process used to remove it involves precipitation of the mucilage using ethanol (SÁENZ, 2004). However, the use of ethanol in food applications is considered increasingly unfavourable (MOHAMED; MANSOORI, 2002), and hence the use of membrane processes to separate the mucilage and obtain a clarified juice permeate appears to show good potential. Sáenz et al. (2004) showed that the mucilage fraction has extensive non-food uses including the restoration of historical buildings, due to its properties as an organic adhesive when used in combination with lime, and food uses as an emulsifier in the stabilization of emulsions and suspensions. The mucilage is a negatively charged polyelectrolyte (SÁENZ et al., 2004), and its viscosity is affected by the $\mathrm{pH}$ and $\mathrm{Ca}^{+2}$ ions, that interfere in the repulsion of the negative charges, thereby resulting in strong intermolecular repulsion. The variation in the mucilage composition of different cactus species has not yet been determined. The Opuntia ficus-indica mucilage is composed of arabinose, galactose, galacturonic acid, rhamnose and xylose, although the concentrations of these components differ depending on various factors, including the region and agroclimatic conditions (SÁENZ et al., 2004). Some studies assume a mucilage structure with a molecular weight from $2.3 \times 10^{4}$ to $4.3 \times 10^{6}$ (SÁENZ et al., 2004); however, the actual size could be higher because of water absorption.

The present authors postulated that it was possible to separate the mucilage using MF membranes without any additional processing, due to its large size. Cassano et al. (2010) used enzymes to clarify the cactus pear juice obtained from a yellow variety; however, the enzyme decreased the size of the mucilage, thereby altering the physical properties of the biopolymer. The mucilage recovered might have many innovative applications in the food industry that have not yet been explored, because this novel product is not yet available in structurally and functionally unchanged forms. Thus the possibility of recovering this fraction using an MF process could provide new opportunities for the use of this material, and this work aims to study the clarification of purple cactus pear juice by MF to obtain a mucilage-free solution that contains the betalain pigments.

The aim of this work was to demonstrate that MF could be used to clarify cactus pear juice without any additional separation process, in order to obtain a mucilage-free permeate that retains the natural properties of the betalains.

\section{Materials and methods}

\subsection{Cactus pear pulp preparation}

The pulp was obtained from purple cactus pears (Opuntia ficus-indica) that were collected from a plantation located in the Antumapu Experimental Station of the
University of Chile in Santiago, Chile. The fruits were washed, peeled and pulped using a tomato screw press at room temperature $\left(15\right.$ to $18{ }^{\circ} \mathrm{C}$ ) to separate the small seeds from the pulp. The remaining fraction was screened to remove whole pieces of pulp and then packed into polypropylene bags and frozen at $-18^{\circ} \mathrm{C}$ until use. All the pulp used in the experiments was produced at the same time.

Equation 1 shows the pulp efficiency $\left(E_{e}\right)$, where $m p$ is the pulp mass and $\mathrm{mt}$ is the cactus pear mass (without processing, including the peel). This value for efficiency can be used to calculate the scale-up of the process used to obtain the pigment.

$$
\mathrm{E}_{\mathrm{e}}=\mathrm{mp} / \mathrm{mt} \times 100(\%)
$$

The feed solution used in the MF experiments was represented by the pulp, which was treated using the method described above and then diluted with distilled water (1:1). The pulp was diluted to extract the betalain pigments from the mucilage- containing pulp, since the pigment is highly hydrophilic at $20 \pm 0.5^{\circ} \mathrm{C}$, which is the same temperature used in the MF experiments. After dilution, the fluid was ready for use in the MF process.

\subsection{Analytical methods}

The soluble solids ( $\left.{ }^{\circ} \mathrm{Brix}\right), \mathrm{pH}$ and acidity were determined according to AOAC methods (CUNNIFF, 1996). The turbidity, used as an indicator of mucilage removal, was determined using a Hanna turbidimeter (HI 93703), and total sugar was determined using the anthrone reagent method (OSBORNE; VOOGT, 1986).

The betalain content was analysed spectrophotometrically according to Stintzing et al. (2005), and the betacyanin and betaxanthin pigments were measured at $535 \mathrm{~nm}$ and $484 \mathrm{~nm}$, respectively. The betalain profile was determined by HPLC (Merck Hitachi) using a photodiode-array detector and a RP-18 column $(5 \mu \mathrm{m} \times 4.6 \mathrm{~mm}$ i.d. $\times 25 \mathrm{~cm})$ (FERNÁNDEZLÓPEZ; ALMELA, 2001).

The total polyphenolic compound content was determined using the Folin-Ciocalteu reagent (SINGLETON; ROSSI, 1965). The mucilage test was performed according to the method described by Sepúlveda et al. (2007), and the antioxidant capacity was evaluated using the Ferric Reducing Ability of Plasma (FRAP) assay (BENZIE; STRAIN, 1996).

All analyses were carried out in triplicate, and the statistical significance of the results was analysed by ANOVA using the commercially available software Statgraphics Centurion XVI. 


\subsection{Microfiltration}

Table 1 shows the characteristics of the laboratoryscale MF membranes used in the present experiments.

All experiments with the polymeric and ceramic membranes were carried out in a non-steady-state mode (Figure 1). The experiments with polymeric membranes used a flat, stainless steel, high-pressure cell that was developed and designed by the GKSS Research Centre (Geesthacht, Germany), although some modifications were made at the INPROMEM Laboratories (Chile) (CANCINO-MADARIAGA et al., 2011). The experiments with ceramic membranes used a tubular stainless steel housing (Tami, France). The flow was forced through positive displacement pumps (PA411 for the ceramic membranes and PA2511 for the polymeric membranes; Fluid-o-Tech, USA). The temperature was controlled using a RESUN Chiller (C-1500) and the permeate flux was measured using a Shimadzu analytical balance (BX 4200). In this system, the permeate and the concentrate were the clarified juice and the mucilage fraction, respectively.

The percentage of betalain mass recovery (MR) was calculated using Equation 2:

$M R=m_{p} / m_{i} \times 100$

where $m_{p}$ is the mass of betalain in the permeate and $\mathrm{m}_{\mathrm{i}}$ is the mass of betalain in the initial feed solution (the betalain mass was expressed as the amount of betanin equivalents, or $\mathrm{MR}_{\mathrm{b}}$, and indicaxanthin equivalents, or $\left.M R_{\mathrm{i}}\right)$.

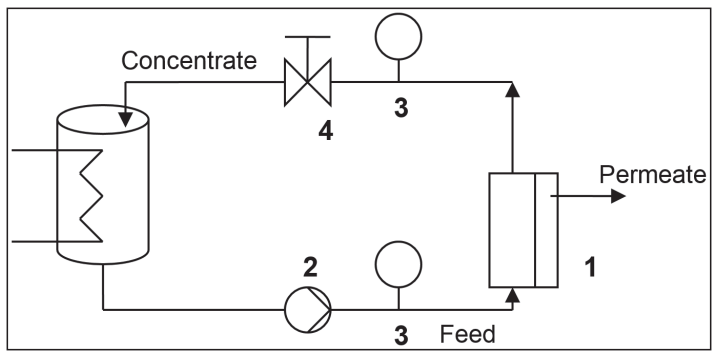

Figure 1. The total recirculation system in a non-steady state: (1) a flat, high-pressure cell or tubular housing, (2) a pump, (3) manometers and (4) a valve.
The percentage concentration of the recovered betalain (CR) was calculated using Equation 3:

$\mathrm{CR}=\mathrm{C} / \mathrm{C}_{\mathrm{i}} \times 100$

where $C_{p}$ is the betalain concentration in the permeate and $\mathrm{C}_{i}$ is the betalain concentration in the feed solution (expressed as betanin equivalents, or $\mathrm{CR}_{b}$, and indicaxanthin equivalents, or $\mathrm{CR}_{\mathrm{i}}$ ).

The efficiency of the clarification process $\left(e_{c}\right)$ was determined using Equation 4:

$e_{c}=\left(1-{ }^{N T U_{p}} / \mathrm{NTU}_{f}\right) \times 100(\%)$

where $\mathrm{NTU}_{\mathrm{p}}$ and $\mathrm{NTU}_{\mathrm{f}}$ are the permeate turbidity and the feed solution turbidity (NTU units), respectively. A higher value for $e_{c}$ indicates a lower permeate turbidity.

The volumetric reduction rate (VRR) was defined as the ratio between the feed volume and the concentrate volume as expressed in Equation 5:

$$
\operatorname{VRR}=\frac{V_{f}}{V_{c}}
$$

where $V_{f}$ is the feed volume at the beginning of the experiment and $V_{c}$ is the concentrate volume at the end of the experiment.

A liquid phase is required In MF experiments and a lower viscosity is desirable. The hydrophilic extraction of the pigment from the pulp was performed at room temperature by adding water in a ratio of 1:1. This fluid constituted the feed solution that was used for all the MF experiments.

The MF process was tested on a laboratory scale using a feed volume of $3 \mathrm{~L}$ at $20^{\circ} \mathrm{C}$ and two transmembrane pressure levels (TMP), 0.64 and 0.84 bar, to identify the level that provided the highest percentage of betalain recovery, which was calculated using Equation 2.

All the ceramic membrane experiments were carried out using the same membrane, which was cleaned using the following cleaning protocol: (1) pure water (distilled water with a conductivity lower than $10 \mu \mathrm{S} / \mathrm{cm}$ ),

Table 1. Laboratory-scale membrane characteristics.

\begin{tabular}{lcc}
\multicolumn{1}{c}{ Characteristics } & Polymeric membrane & Ceramic membrane \\
Material and denomination & Polysulphone (PS), GRM 0.1 PP & $\mathrm{TiO}_{2}+\mathrm{ZrO}_{2}$ \\
Manufacturer & Alfa Laval - Denmark & Tami - France \\
Cut-off & $0.2 \mu \mathrm{m}$ & $0.2 \mu \mathrm{m}$ \\
Area $\left(\mathrm{m}^{2}\right)$ & 0.0104 & 0.0047 \\
Configuration & Flat sheet in disc form & Monotubular \\
Resistance $\left(\mathrm{m}^{-1}\right)^{\mathrm{a}}$ & $2.50 \times 10^{12}$ & $2.46 \times 10^{11}$ \\
\hline
\end{tabular}

a The membrane resistance was experimentally measured at $20^{\circ} \mathrm{C}$ using distilled water with a conductivity below $10 \mu \mathrm{S} / \mathrm{cm}$, in accordance with Cancino-Madariaga et al. (2011). 
(2) $0.5 \%$ Ultrasil 11 (Henkel, Ecolab) at $50^{\circ} \mathrm{C}$ for $15 \mathrm{~min}$, and (3) wash at least three times with pure water until the Ultrasil was removed from the circuit. Both the $\mathrm{pH}$ and conductivity tests were then carried out to verify that the latter criterion had been achieved.

The experiments with polymeric membranes were carried out with new membranes but each membrane was cleaned with pure water in accordance with the manufacturer's instructions and the author's own experience. The cleaning procedure used was as follows: (1) wash with pure water, (2) 0.5\% Ultrasil 10 (Henkel, Ecolab) at $55^{\circ} \mathrm{C}$ for $30 \mathrm{~min}$, and (3) wash at least three times with pure water until the Ultrasil was removed from the circuit. A pH test was then performed to verify that the latter criterion had been achieved.

ANOVA and Tukey's test were used to analyse the differences between the parameters studied and Statgraphics Centurion XVI was used for all the statistical analyses.

\section{Results and discussion}

The extraction efficiency $\left(E_{e}\right)$ of the cactus pear pulp processing procedure, evaluated in accordance with Equation 1, was $42.6 \%$. This result can be applied to scale-up the process to approach the amount required to produce the desired amount of juice or pulp. The peel of this type of cactus pear is purple and contains betalains, which implies that it could also be separated using the results shown below to increase the pigment yield of the process.

\subsection{MF results}

Figure 2 presents the permeate flux (J) obtained using the ceramic and polymeric membranes with TMPs of 0.64 and 0.84 bar. These results show significant differences ( $p$-value $\leq 0.05$ ) between the curves obtained.

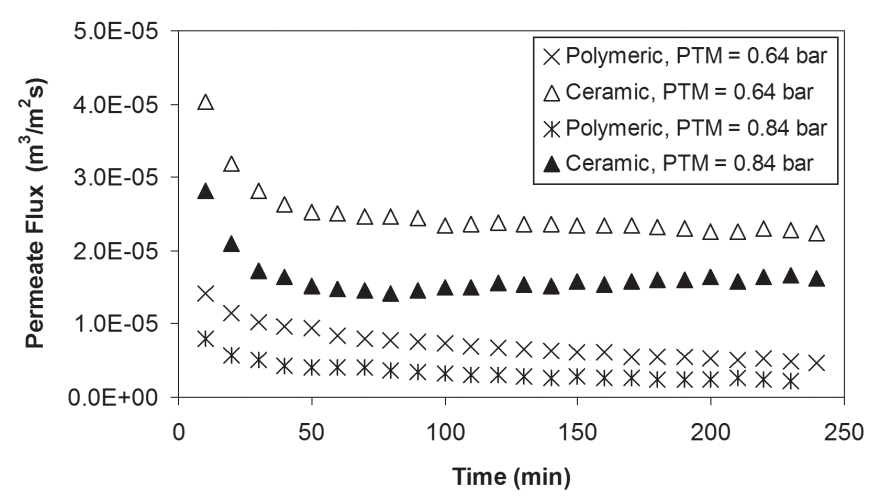

Figure 2. Permeate flux obtained using laboratory scale polymeric and ceramic membranes with TMPs of 0.64 and 0.84 bar at $20^{\circ} \mathrm{C} \pm 0.5$.
After ca. 50 min, the flux obtained through both membranes was stable, and no additional changes were observed until the experiments were stopped at ca. 240 min. This behaviour was independent of the TMP and the membrane material used. It was also clear that a lower TMP resulted in a higher flux and that, at both pressure levels, the ceramic membrane exhibited approximately twice the flux observed with the polymeric membranes. Similar behaviour was observed by Cassano et al. (2010) during the MF of de-pectinised cactus pear juice using a polymeric membrane.

The plateau reached after 50 min with both TMPs was due to the development of concentration polarisation fouling, which is produced by the biopolymer in the feed solution (GIRARD; FUKUMOTO, 2000). However, differences were observed between the fluxes obtained using the different TMPs. At the lower TMP, a higher flux and less compacting of the biopolymer was observed. Cassano et al. (2010) observed that a flat and stable zone was reached after ca. 250 min using a flux of $1.355 \times 10^{-5} \mathrm{~m}^{3} /\left(\mathrm{m}^{2} \mathrm{~s}\right)$. The results shown in Figure 2 for 0.64 bar were higher than those obtained by this author, in fact, the flux almost doubled using the ceramic membrane. However, the flux decreased at higher pressures, an effect similar to the results described by Cassano at a higher TMP (2.2 bar).

Figure 3 shows the VRRs obtained with both membranes and both TMP levels. As can be seen, significant differences ( $p$-value $\leq 0.05$ ) were observed between the membranes. The VRR obtained with the ceramic membrane was significantly higher at 0.64 bar, and a higher VRR is desirable, because it indicates a higher permeate volume. At the end of the filtration process (i.e., after $240 \mathrm{~min}$ ), the VRR obtained with the ceramic membrane at 0.64 bar was approximately $13.6 \%$ higher than the other results obtained. No statistically significant differences were observed between the use

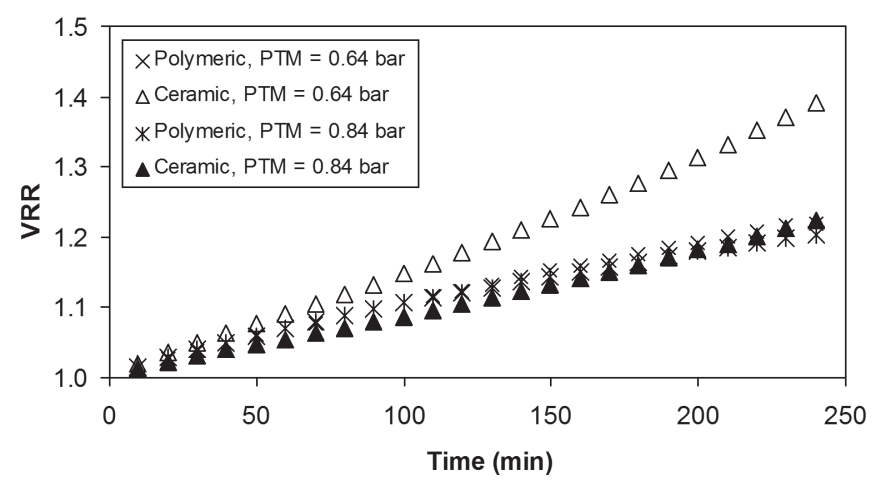

Figure 3. VRR values obtained with laboratory scale polymeric and ceramic membranes with TMPs of 0.64 and 0.84 bar at $20{ }^{\circ} \mathrm{C} \pm 0.5$. 
of the ceramic membrane at $0.84 \mathrm{bar}$ and the polymeric membrane at 0.64 or 0.84 bar.

Table 2 shows differences between the permeates obtained using the polymeric and ceramic membranes at the end of the process. It can be seen that the turbidity of all permeates was 0 NTU, which indicates total removal of the mucilage. This result was confirmed by the mucilage test, which also showed negative results. For betanin (the red pigment), $\mathrm{CR}_{\mathrm{b}}$ describes the concentration in the permeate. Comparing the $\mathrm{CR}_{\mathrm{b}}$ values obtained with both membranes, the best performance was obtained with the ceramic membrane at low TMP. The same result was obtained when the betanin mass $\left(\mathrm{MR}_{\mathrm{b}}\right)$ was analysed. A higher $\mathrm{CR}_{b}$ value indicates greater transmission of the pigment, whereas a higher $\mathrm{MR}_{\mathrm{b}}$ value indicates a greater permeate flow; thus, $\mathrm{CR}_{\mathrm{b}}$ is different from $\mathrm{MR}_{\mathrm{b}}$.

Since MF is a clarification step and clarification was fully achieved (ec $=100 \%)$ under all conditions with all membranes, the most important parameter is the level of betalain recovery (i.e., MR). Undoubtedly, the ceramic membrane used at 0.64 bar expressed a larger mass of betanin into the permeate fraction and yielded $48 \%$ more betalain than the polymeric membrane under the same conditions. The other parameters shown in Table 2, such as the permeate flow, $\mathrm{J}_{240}, \mathrm{CR}, \mathrm{MR}$ and VRR, were significantly higher ( $p$-value $<0.05$ ) for the ceramic membrane at 0.64 bar.

This type of study typically focuses on the value obtained for CR and not for MR. However as observed from the results obtained, the $\mathrm{CR}$ values were always higher and could lead to erroneous conclusions if the aim was to obtain the mass of pigment or a specific component.

Chromatography was used to identify the betalains obtained under the different flow conditions (feed, fraction retained and permeate) used with the ceramic membrane. Figure 4 depicts the chromatogram of the MF feed further separated using the ceramic membrane at 0.64 bar. In this figure, peaks 1,2 and 3 represent indicaxanthin, betanin and isobetanin, respectively (FERNÁNDEZLÓPEZ; ALMELA, 2001; SÁENZ et al., 2009). The same profiles were obtained in the permeate and concentrate (data not shown) demonstrating that the betalains were not destroyed during the MF process. Other molecules present in the permeate or concentrate fractions showing the same absorption maximum (535 nm) could only be identified via chromatography. This result may be attributed to some type of degradation as a result of the temperature or other conditions used, such as high shear stress. In such cases, the chromatograms would be different.

Table 3 shows the physical and chemical characteristics of the feed, permeate and fractions retained obtained using the MF process with a ceramic membrane at 0.64 bar.

The statistical analysis showed that no significant differences existed between the soluble solids contents, $\mathrm{pH}$ values and densities of the permeate and concentrate fractions. However, the biopolymer was retained in the concentrate, as indicated by the turbidity value. The soluble solids content was a better indicator of the sugar content than the mucilage content. In addition, the total sugars, betalains, polyphenols and antioxidant activities in the different flows were significantly different ( $p$-value < 0.05). The value obtained for the permeate antioxidant capacity was $77.4 \%$ of the initial value, which may be explained in part by the retention of antioxidant molecules by the membrane. This value confirms that the negative effects produced by the MF process on

Table 2. Physical and chemical characteristics of the permeate obtained after MF for 240 min using ceramic and polymeric membranes at 0.64 and 0.84 bar.

\begin{tabular}{|c|c|c|c|c|}
\hline \multirow{2}{*}{ Membrane / TMP } & \multicolumn{2}{|c|}{ Polymeric } & \multicolumn{2}{|c|}{ Ceramic } \\
\hline & 0.64 & 0.84 & 0.64 & 0.84 \\
\hline Turbidity (NTU) & $0.0 \pm 0.0 a$ & $0.0 \pm 0.0 \mathrm{a}$ & $0.0 \pm 0.0 \mathrm{a}$ & $0.0 \pm 0.0 \mathrm{a}$ \\
\hline$e_{c}(\%)^{a}$ & $100 \pm 0.0 \mathrm{a}$ & $100 \pm 0.0 \mathrm{a}$ & $100 \pm 0.0 \mathrm{a}$ & $100 \pm 0.0 \mathrm{a}$ \\
\hline Permeate flow (g/h) & $140.0 \pm 0.0 \mathrm{~b}$ & $127.5 \pm 0.0 b$ & $210.0 \pm 0.0 \mathrm{a}$ & $140.0 \pm 0.0 \mathrm{~b}$ \\
\hline $\mathrm{J}_{240}\left(\mathrm{~m}^{3} / \mathrm{m}^{2} \mathrm{~s}\right)^{\mathrm{b}}$ & $5.44 \cdot 10-6 c$ & $2.50 \cdot 10-6 d$ & $2.30 \cdot 10-5 a$ & $1.13 \cdot 10-5 b$ \\
\hline $\mathrm{CR}_{\mathrm{b}} \mathrm{c}(\%)$ & $62.0 \pm 0.3 b$ & $69.5 \pm 0.9 a$ & $70.2 \pm 0.5 a$ & $67.4 \pm 0.0 a$ \\
\hline $\mathrm{CR}_{\mathrm{i}}{ }^{\mathrm{d}}(\%)$ & $60.6 \pm 5.8 b$ & $72.7 \pm 0.1 \mathrm{a}$ & $70.7 \pm 3.3 a$ & $66.6 \pm 0.0 b$ \\
\hline $\mathrm{MR}_{\mathrm{b}} \mathrm{e}(\%)$ & $13.2 \pm 0.1 b$ & $10.3 \pm 0.2 b$ & $20.6 \pm 0.1 \mathrm{a}$ & $12.8 \pm 0.0 b$ \\
\hline $\mathrm{MR}_{\mathrm{i}}{ }^{\dagger}(\%)$ & $13.4 \pm 1.1 b$ & $10.7 \pm 0.01 b$ & $20.4 \pm 0.8 a$ & $13.1 \pm 0.0 b$ \\
\hline $\mathrm{VRR}^{g}$ & $1.2 \pm 0.0 b$ & $1.2 \pm 0.0 \mathrm{~b}$ & $1.4 \pm 0.0 \mathrm{a}$ & $1.2 \pm 0.0 \mathrm{~b}$ \\
\hline
\end{tabular}

${ }^{a} e_{c}(\%)$ : clarification efficiency. ${ }^{b} J_{240}:$ permeate flux after 240 min. ${ }^{\circ} \mathrm{CR}_{b}$ : concentration of betalain recovered, expressed as betanin equivalents. ${ }^{d} C_{\text {: }}$ : concentration of betalain recovered, expressed as indicaxanthin equivalents. ${ }^{e} \mathrm{MR}_{b}$ : mass of betalain recovered, expressed as betanin equivalents. ${ }^{\dagger} \mathrm{MR}_{\mathrm{i}}$ : mass of betalain recovered, expressed as indicaxanthin equivalents. ${ }^{9}$ VRR: volumetric reduction rate. a-d: Different letters mean statistical differences between membranes for each TMP $(p<0.05)$. 

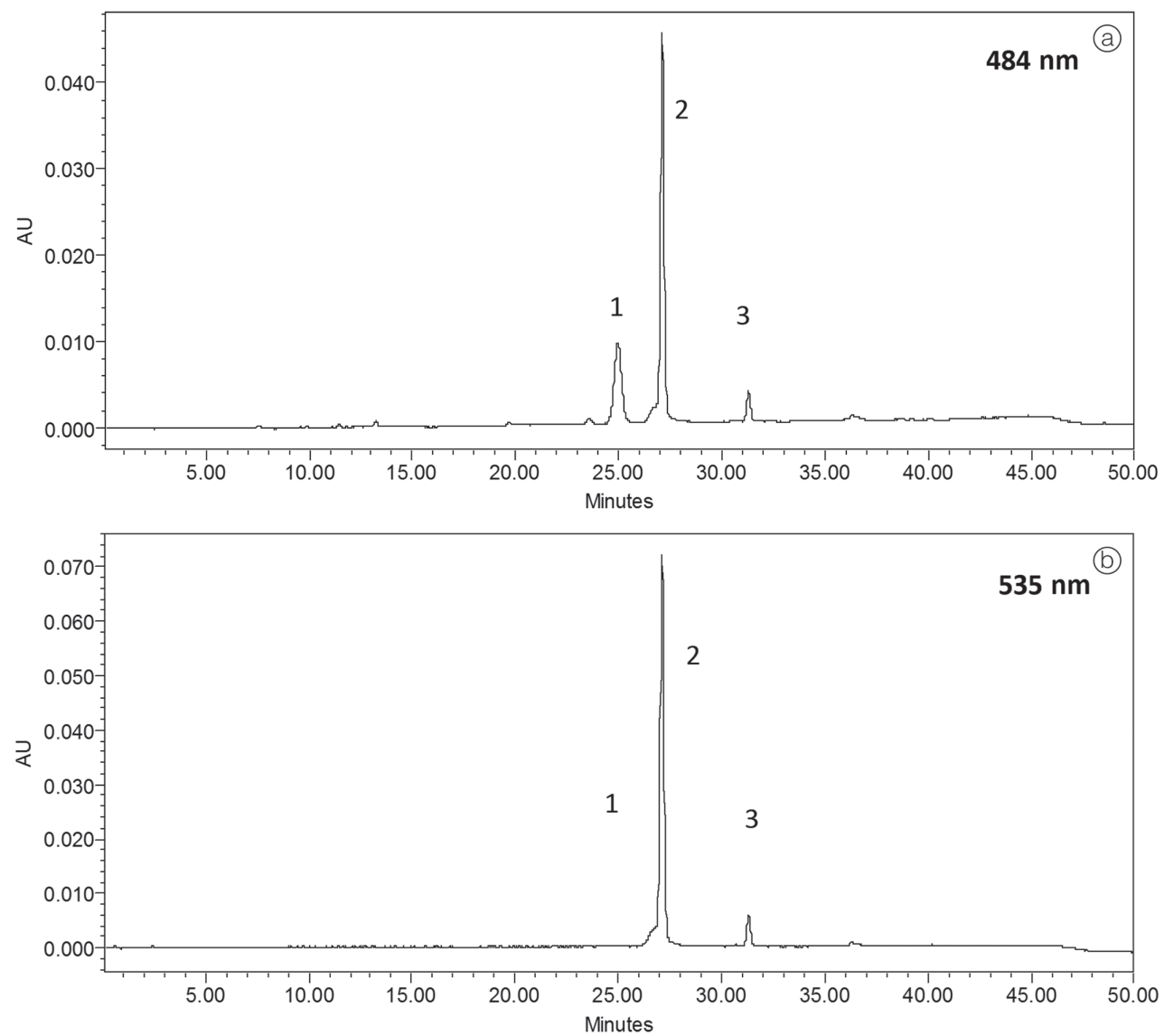

Figure 4. Chromatograms of the MF feed solution. The betalains were analysed using HPLC, resulting in the following peaks: indicaxanthin (1), betanin (2) and isobetanin (3) .

Table 3. Physical and chemical characteristics of the feed, permeate and retentate solutions obtained by MF using a ceramic membrane at 0.64 bar.

\begin{tabular}{|c|c|c|c|}
\hline & $\begin{array}{c}\text { Feed } \\
\text { (Pulp:water (1:1)) }\end{array}$ & Permeate & Retentate \\
\hline Soluble solids ( ${ }^{\circ}$ Brix at $20^{\circ} \mathrm{C}$ ) & $7.1 \pm 0.5 \mathrm{a}$ & $6.9 \pm 0.2 \mathrm{a}$ & $7.1 \pm 0.3 a$ \\
\hline Total sugars (\%) & $6.6 \pm 0.0 \mathrm{a}$ & $7.2 \pm 0.9 a$ & $7.3 \pm 0.0 \mathrm{a}$ \\
\hline $\mathrm{pH}$ & $6.4 \pm 0.2 \mathrm{a}$ & $6.7 \pm 0.1 \mathrm{a}$ & $6.8 \pm 0.1 \mathrm{a}$ \\
\hline Acidity (\% citric acid) & $0.020 \pm 0.00 c$ & $0.056 \pm 0.003 a$ & $0.035 \pm 0.01 b$ \\
\hline Density & $1.046 \pm 0.02 \mathrm{a}$ & $1.017 \pm 0.04 \mathrm{a}$ & $1.021 \pm 0.04$ \\
\hline Turbidity (NTU) & $1226.7 \pm 64.3 b$ & $0.0 \pm 0.00 \mathrm{c}$ & $2283.3 \pm 56.0 \mathrm{a}$ \\
\hline Betacyanins (mg BE/L) ${ }^{a}$ & $131.7 \pm 1.1 b$ & $97.0 \pm 0.2 c$ & $145.7 \pm 0.1 \mathrm{a}$ \\
\hline Betaxanthins (mg IE/L) $)^{\mathrm{b}}$ & $48.7 \pm 0.7 b$ & $34.7 \pm 0.1 c$ & $52.3 \pm 0.1 \mathrm{a}$ \\
\hline Total polyphenols (mg GAE/L) ${ }^{c}$ & $196.7 \pm 0.0 b$ & $245.3 \pm 4.0 \mathrm{a}$ & $120.8 \pm 8.9 c$ \\
\hline Antioxidant activity (mM/L) & $3.1 \pm 0.1 \mathrm{a}$ & $2.4 \pm 0.2 b$ & $1.9 \pm 0.1 b$ \\
\hline
\end{tabular}

${ }^{a} \mathrm{BE}$ : betanin equivalents. ${ }^{\mathrm{b}} \mathrm{IE}$ : Indicaxanthin equivalents. ${ }^{\circ} \mathrm{GAE}$ : gallic acid equivalents. a-c: Different letters mean significant differences between the feed, permeate and retentate for each parameter $(p<0.05)$.

the bioactive properties of the liquid were minimal. However, the values listed in Table 3 for the polyphenolic compound concentrations may be misleading, because they show better results than those obtained in the mass balance analysis (Table 4). Thus, the amount of polyphenolic compounds in the permeate was $37 \%$ of the initial amount. The amounts of polyphenols may increase with the consecutive water extraction stages since the water molecules are smaller than the pores of the MF membrane and are only retained by the gel layer formed by the mucilage. Consecutive water extractions may improve the permeation of some polyphenols, but would simultaneously increase the volume and cost of the overall process. However, this analysis is beyond the 
Clarification of purple cactus pear juice using microfiltration membranes to obtain a solution of betalain pigments VERGARA, C. et al.

Table 4. Mass balance of the MF process.

\begin{tabular}{lrrr} 
& Feed & Permeate & Retentate \\
Volume $(\mathrm{L})$ & 3.00 & 0.84 & 2.00 \\
Betacyanins $\left(\mathrm{mg} \mathrm{BE}^{\mathrm{a}}\right)$ & 395.10 & 81.48 & 291.40 \\
Betaxanthins $\left(\mathrm{mg} \mathrm{IE}^{\mathrm{b}}\right)$ & 146.10 & 29.15 & 104.60 \\
Total polyphenols $\left(\mathrm{mg} \mathrm{GAE}^{\mathrm{c}}\right)$ & 590.10 & 218.12 & 241.54 \\
\hline
\end{tabular}

${ }^{a} \mathrm{BE}$ : betanin equivalents. ${ }^{\mathrm{b}} \mathrm{IE}$ : Indicaxanthin equivalents. ${ }^{\mathrm{c}} \mathrm{GAE}$ : gallic acid equivalents.

scope of this study and the optimal number of extraction steps remains unknown.

Betacyanins (red pigments) in the permeate represent $20.6 \%$ of the mass in the initial solution and the total pigment in the permeate represents $20.4 \%$ of the mass in the initial solution. However, in other studies (CASSANO et al., 2010), the pigment was not found in the permeate and was instead retained in the concentrate during the MF process. To improve the recovery of this pigment, it may be useful to carry out a study using consecutive extraction steps, since increasing the number of extraction stages may recover more pigment in the permeate. However, this study showed that it is possible to extract the pigment in the permeate, which could then be concentrated via further steps such as ultrafiltration or nanofiltration, since the mucilage is no longer in the solution.

In addition, the mucilage recovered in the retained fraction from the MF membrane could be used for many new applications in the food industry that have not yet been explored. However, the mucilage recovered is not ready for use and must be separated from the pigment via several water extraction stages, as previously proposed. During this process, the effect of shear stress must be considered to ensure that the functionalities of the recovered biopolymer have not been lost. Thus, additional studies must be carried out in this area.

The mucilage, as already mentioned, is negatively charged. Hydrophilic membranes, including both the PS and ceramic membranes used in this study, are also negatively charged. However, differences between these membranes exist that depend on the type and number of chemical groups that form the active layer, where the separation is obtained. Ceramic membranes are more hydrophilic than PS membranes (MELIN; RAUTENBACH, 2007). Therefore, it is likely that the mucilage is repelled more easily when ceramic membranes are used, which would cause a greater flux through the membrane. Additional studies in this area are required to identify the limits of this behaviour, since the $\mathrm{pH}$ and the organic acids and salts present in the solution can also affect and/or interact with the chemical groups on the membrane and change the properties of the biopolymer. To illustrate some differences between ceramic and PS membranes, Figure 5 shows an image of both, in which the contact

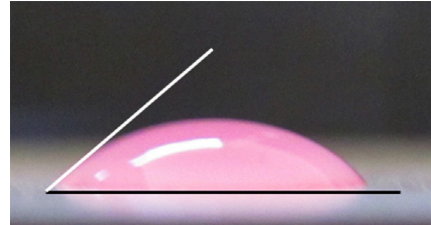

Contact angle: $40^{\circ}$, ceramic

Figure 5. Contact angles observed for the ceramic and polymeric membranes.

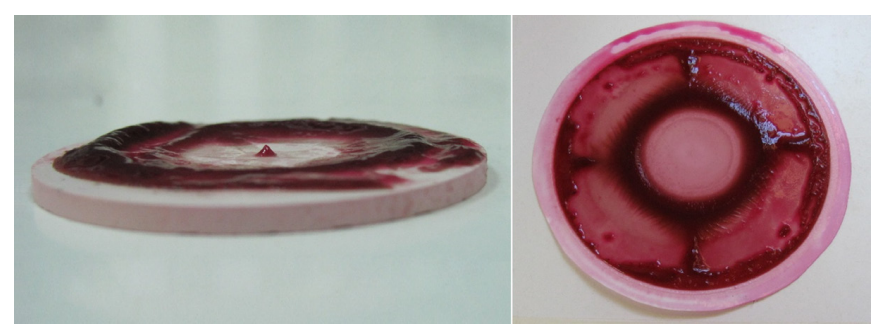

Figure 6. Mucilage retained by the ceramic (left) and polymeric (right) membranes.

angle formed between the drop and the membrane surface can be observed. The images were obtained using the same contact duration. In this figure, the ceramic membrane exhibits a smaller contact angle with the surface of the membrane, a behaviour that agrees with the results reported by Melin and Rautenbach (2007).

Figure 6 shows images of the mucilage retained by the polymeric membrane and a ceramic membrane disc, which is composed of the same material as the multitubular ceramic membrane used in this study. This figure illustrates the mucilage retained during the membrane separation process. However, further studies on the mucilage and its physical and chemical characteristics are required.

\section{Conclusions}

The TMP used in the MF process for the clarification of cactus pear juice is crucial for the flux obtained, regardless of the membrane used. A lower TMP produces a greater flux. However, in this study, ceramic membranes exhibited a greater flux than the polymeric membranes, regardless of the TMP.

It is not necessary to use enzymes to decrease fouling of the membrane used for the clarification of cactus 
Clarification of purple cactus pear juice using microfiltration membranes to obtain a solution of betalain pigments VERGARA, C. et al.

pear juice. With an MF membrane, the juice clarification efficiency was $100 \%$ and the mucilage was separated in the retained fraction. The ceramic membrane worked best for the clarification of cactus pear juice when using a permeate flow of $210 \mathrm{~g} / \mathrm{h}$, and $20.6 \%$ of the betacyanin mass and $20.4 \%$ of the betaxanthin mass were recovered in the permeate after $4 \mathrm{~h}$ of processing, as well as $70 \%$ of the betalain. Moreover, MF using ceramic membranes represents a gentle separation method that does not destroy the pigment molecules. The permeate fraction proved to be a source of bioactive components such as polyphenols and betalains, yielding a clarified juice with functional and health-giving properties.

\section{Acknowledgements}

The authors would like to thank FONDECYT for awarding Grant No. 1110126 and also acknowledge Dr. Frank Lipnizki of the Alfa Laval Company for supplying the MF membranes and CONICYT Chile for the PhD scholarship granted to Ms. Cristina Vergara.

\section{References}

AZEREDO, H. M. C. Betalains: properties, sources, applications, and stability - a review. International Journal of Food Science \& Technology, Oxford, v. 44, n. 12, p. 2365-2376, 2008. http:// dx.doi.org/10.1111/j.1365-2621.2007.01668.x.

BENZIE, I. F.; STRAIN, J. J. The ferric reducing ability of plasma (FRAP) as a measure of "antioxidant power": the FRAP assay. Analytical Biochemistry, New York, v. 239, n. 1, p. 70-76, 1996. http://dx.doi.org/10.1006/abio.1996.0292. PMid:8660627.

CAI, Y.; SUN, M.; CORKE, H. Colourant properties and stability of Amaranthus betacyanin pigments. Journal of Agricultural and Food Chemistry, Easton, v. 46, n. 11, p. 4491-4495, 1998. http://dx.doi.org/10.1021/jf980457g.

CANCINO-MADARIAGA, B.; KAISER, S.; KASAHARA, I.; DÍAZ, P.; ALVAREZ, J.; ASTUDILLO, C. Pulsed ultraviolet radiation, microfiltration and chlorine dioxide on Alyciclobacillus acidoterrestris. Journal of Biotechnology, Amsterdam, v. 136S, p. S717-S742, 2008.

CANCINO-MADARIAGA, B.; HURTADO, C. F.; RUBY, R. Effect of pressure and $\mathrm{pH}$ ammonium retention for nanofiltration and reverse osmosis membranes to be use in recirculation aquaculture systems (RAS). Aquacultural Engineering, Essex, v. 45, n. 3, p. 103-108, 2011. http://dx.doi.org/10.1016/j. aquaeng.2011.08.002.

CASSANO, A.; CONIDI, C.; DRIOLI, E. Physico-chemical parameters of cactus pear (Opuntia ficus-indica) juice clarified by microfiltration and ultrafiltration processes. Desalination, Amsterdam, v. 250, n. 3, p. 1101-1104, 2010. http://dx.doi. org/10.1016/j.desal.2009.09.117.
CASTELLAR, M. R.; OBÓN, J. M.; FERNÁNDEZ-LÓPEZ, J. A. The isolation and properties of a concentrated red-purple betacyanin food colourant from Opuntia stricta fruits. Journal of the Science of Food and Agriculture, London, v. 86, n. 1, p. 122-128, 2006. http://dx.doi.org/10.1002/jsfa.2285.

CASTELLAR, R.; OBÓN, J. M.; ALACID, M.; FERNÁNDEZLÓPEZ, J. A. Color properties and stability of betacyanins from Opuntia fruits. Journal of Agricultural and Food Chemistry, Easton, v. 51, n. 9, p. 2772-2776, 2003. http://dx.doi.org/10.1021/ jf021045h. PMid:12696971.

CHERYAN, M. Ultrafiltration and microfiltration handbook. Lancaster: Technomic Publishing, 1998. p. 1-3.

CUNNIFF, P. (Ed.). Official methods of analysis of the Association of Official Analytical Chemists. 16th ed. Gaithersburg: AOAC, 1996.

DELGADO-VARGAS, F.; JIMÉNEZ, A. R.; PAREDES-LÓPEZ, O. Natural pigments: carotenoids, anthocyanins, and betalains-characteristics, biosynthesis, processing, and stability. Critical Reviews in Food Science and Nutrition, Boca Raton, v. 40, n. 3 , p. 173-289, 2000. http://dx.doi.org/10.1080/10408690091189257. PMid:10850526.

DÍAZ, F.; SANTOS, E. M.; FILARDO, S.; VILLAGÓMEZ, R.; SCHEINVAR, L. Colorant extraction from a red prickly pear (Opuntia lasiacantha) for food application. Electronic Journal of Environmental, Agricultural and Food Chemistry, Easton, v. 5, p. $1330-1337,2006$.

ESPINA, V.; JAFFRIN, M. Y.; DING, L.; CANCINO-MADARIAGA, $B$. Fractionation of pasteurized skim milk proteins by dynamic filtration. Food Research International, Barking, v. 43, n. 5, p. 1335-1346, 2010. http://dx.doi.org/10.1016/j. foodres.2010.03.023.

FERNÁNDEZ-LÓPEZ, J. A.; ALMELA, L. Application of highperformance liquid chromatography to the characterization of the betalain pigments in prickly pear fruits. Journal of Chromatography. A, Amsterdam, v. 913, n. 1-2, p. 415-420, 2001. http://dx.doi.org/10.1016/S0021-9673(00)01224-3. PMid:11355839.

FORNI, E.; POLESELLO, A.; MONTEFIORI, D.; MAESTRELLI, A. High performance liquid chromatographic analysis of the pigments of blood-red prickly pear (Opuntia ficus-indica). Journal of Chromatography. A, Amsterdam, v. 593, n. 1-2, p. 177-183, 1992. http://dx.doi.org/10.1016/0021-9673(92)80284-2.

GALATI, E. M.; MONDELLO, M. R.; GIUFFRIDA, D.; DUGO, G.; MICELI, N.; PERGOLIZZI, S.; TAVIANO, M. F. Chemical characterization and biological effects of Sicilian Opuntia ficus indica (L.) mill. Fruit juice: antioxidant and antiulcerogenic activity. Journal of Agricultural and Food Chemistry, Easton, v. 51 , n. 17 , p. $4903-4908,2003$. http://dx.doi.org/10.1021/ jf030123d. PMid:12903943.

GENTILE, C.; TESORIERE, L.; ALLEGRA, M.; LIVREA, M. A.; D'ALESSIO, P. Antioxidant betalains from cactus pear (Opuntia 
Clarification of purple cactus pear juice using microfiltration membranes to obtain a solution of betalain pigments VERGARA, C. et al.

ficus-indica) inhibit endothelial ICAM-1 expression. Annals of the New York Academy of Sciences, New York, v. 1028, n. 1, p. 481-486, 2004. http://dx.doi.org/10.1196/annals.1322.057. PMid:15650274.

GIRARD, B.; FUKUMOTO, L. R. Membrane processing of fruit juices and beverages: a review. Critical Reviews in Food Science and Nutrition, Boca Raton, v. 40, n. 2, p. 91-157, 2000. http://dx.doi.org/10.1080/10408690091189293. PMid:10770272.

HERBACH, K. M.; STINTZING, F. C.; CARLE, R. Betalain stability and degradation: structural and chromatic aspects. Journal of Food Science, Chicago, v. 71, n. 4, p. R41-R50, 2006. http:// dx.doi.org/10.1111/j.1750-3841.2006.00022.x.

KUTI, J. Antioxidant compounds from four Opuntia cactus pear fruit varieties. Food Chemistry, London, v. 85, n. 4, p. 527-533, 2004. http://dx.doi.org/10.1016/S0308-8146(03)00184-5

MATSUHIRO, B.; LILLO, L.; SÁENZ, C.; URZÚA, C.; ZÁRATE, O. Chemical characterization of the mucilage from fruits of Opuntia ficus-indica. Carbohydrate Polymers, Barking, v. 63, n. 2 , p. 263-267, 2006. http://dx.doi.org/10.1016/j.carbpol.2005.08.062.

MELIN, T.; RAUTENBACH, R. Membranverfahren. Heidelberg: Springer, 2007. 343 p.

MOHAMED, R. S.; MANSOORI, G. A. The use of supercritical fluid extraction technology in food processing. Food Technology Magazine, London, June 2002

MOSSHAMMER, M. R.; STINTZING, F. C.; CARLE, R. Evaluation of different methods for the production of juice concentrates and fruit powders from cactus pear. Innovative Food Science \& Emerging Technologies, Amsterdam, v. 7, n. 4, p. 275-287, 2006. http://dx.doi.org/10.1016/j.ifset.2006.04.003.

ODOUX, E.; DOMÍNGUES-LÓPEZ, A. Le figuier de barbarie: une source industrielle de betalaines? Fruits, Paris, v. 51, p. 61-78, 1996.

OSBORNE, D. R.; VOOGT, P. Análisis de los nutrientes de los alimentos. Zaragoza: Acribia, 1986. p. 10-15.

SÁENZ, C. Compuestos funcionales y alimentos derivados de Opuntia spp. In: ESPARZA, F. G.; VALDEZ, C. R. D.; MÉNDEZ, C. S. J. (Ed.). El Nopal, tópicos de actualidad. Chapingo: Universidad Autónoma de Chapingo, 2004. p. 211-222.

SÁENZ, C. Utilización agroindustrial del nopal. Rome: FAO, 2006. 165 p. (Boletín de Servicios Agrícolas de la FAO, n. 162).

SÁENZ, C.; SEPÚlVEDA, E.; MATSUHIRO, B. Opuntia spp mucilage's: a functional component with industrial perspectives. Journal of Arid Environments, London, v. 57, n. 3, p. 275-290, 2004. http://dx.doi.org/10.1016/S0140-1963(03)00106-X.

SÁENZ, C.; TAPIA, S.; CHAVEZ, J.; ROBERT, P. Microencapsulation by spray drying of bioactive compounds from cactus pear (Opuntia ficus-indica). Food Chemistry, London, v. 114, n. 2, p. 616-622, 2009. http://dx.doi.org/10.1016/j. foodchem.2008.09.095.
SEMBRIES, S.; DONGOWSKI, G.; MEHRLÄNDER, K.; WILL, F.; DIETRICH, H. Physiologische wirkungen von extraktionssäften asu ápfeln, weinbeeren und roten beten in vitro und am menschen. Deutsche Lebensmittel-Rundschau, Stuttgart, v. 102, p. 350-365, 2006.

SePúlVedA, E.; SÁENZ, C.; ALIAGA, E.; ACEITUNO, C. Extraction and characterization of mucilage in Opuntia spp. Journal of Arid Environments, London, v. 68, n. 4, p. 534-545, 2007. http://dx.doi.org/10.1016/j.jaridenv.2006.08.001.

SEPÚLVEDA, E.; SÁENZ, C.; GÓMEZ, C. Determinación de betanina en ecotipos de tuna roja colectados en Chile. In: CONGRESO NACIONAL, 9.; CONGRESO INTERNACIONAL CONOCIMIENTO Y APROVECHAMIENTO DEL NOPAL, 7., 2003, Zacatecas, Mexico. Anales... Zacatecas: Universidad de Zacatecas, 2003.

SERRIS, G. S.; BILIADERIS, C. G. Degradation kinetics of beetroot pigment encapsulated in polymeric matrices. Journal of the Science of Food and Agriculture, London, v. 81, n. 8 , p. 691-700, 2001. http://dx.doi.org/10.1002/jsfa.864.

SINGLETON, V. L.; ROSSI, J. A. Colorimetry of total phenolics with phosphomolybdic - phosphotungstic acid reagents. American Journal of Enology and Viticulture, Davis, v. 16, p. 144-158, 1965

SREEKANTH, D.; ARUNASREE, M. K.; ROY, K. R.; CHANDRAMOHAN REDDY, T.; REDDY, G. V.; REDDANNA, P. Betanin a betacyanin pigment purified from fruits of Opuntia ficus-indica induces apoptosis in human chronic myeloid leukemia Cell line-K562. Phytomedicine, Jena, v. 14, n. 11, p. 739-746, 2007. http://dx.doi.org/10.1016/j.phymed.2007.03.017. PMid: 17482444

STEVENSON, D. E.; HURST, R. D. Polyphenolic phytochemicals: just antioxidants or much more? Cellular and Molecular Life Sciences: CMLS, Basel, v. 64, n. 22, p. 2900-2916, 2007. http:// dx.doi.org/10.1007/s00018-007-7237-1. PMid:17726576.

STINTZING, F. C.; HERBACH, K. M.; MOSSHAMMER, M. R.; CARLE, R.; YI, W.; SELLAPPAN, S.; AKOH, C. C.; BUNCH, R.; FELKER, P. Color, betalain pattern, and antioxidant properties of cactus pear (Opuntia spp.) clones. Journal of Agricultural and Food Chemistry, Easton, v. 53, n. 2, p. 442-451, 2005. http:// dx.doi.org/10.1021/jf048751y. PMid:15656686.

STINTZING, F. C.; SCHIEBER, A.; CARLE, R. Phytochemical and nutritional significance of cactus pear. European Food Research and Technology, Berlin, v. 212, n. 4, p. 396-407, 2001. http://dx.doi.org/10.1007/s002170000219.

STINTZING, F.; CARLE, R. Functional properties of anthocyanins and betalains in plants, food, and in human nutrition. Trends in Food Science \& Technology, Cambridge, v. 15, n. 1, p. 19-38, 2004. http://dx.doi.org/10.1016/j.tifs.2003.07.004.

TESORIERE, L.; ALLEGRA, M.; BUTERA, D.; LIVREA, M. A. Absorption, excretion, and distribution of dietary antioxidant 
Clarification of purple cactus pear juice using microfiltration membranes to obtain a solution of betalain pigments VERGARA, C. et al.

betalains in LDLs: potential health effects of betalains in humans. The American Journal of Clinical Nutrition, Bethesda, v. 80, n. 4, p. 941-945, 2004. PMid:15447903.

TESORIERE, L.; BUTERA, D.; ALLEGRA, M.; FAZZARI, M.; LIVREA, M. A. Distribution of betalain pigments in red blood cells after consumption of cactus pear fruits and increased resistance of the cells to ex vivo induced oxidative hemolysis in humans. Journal of Agricultural and Food Chemistry, Easton, v. 53, n. 4, p. 1266-1270, 2005. http://dx.doi.org/10.1021/jf048134+. PMid: 15713051. 